\title{
Pathology of the human pituitary adenomas
}

\author{
Robert Y. Osamura $\cdot$ Hanako Kajiya $\cdot$ Mao Takei $\cdot$ \\ Noboru Egashira $\cdot$ Maya Tobita $\cdot$ Susumu Takekoshi $\cdot$ \\ Akira Teramoto
}

Accepted: 27 June 2008 / Published online: 8 August 2008

(C) Springer-Verlag 2008

\begin{abstract}
This article describes pertinent aspects of histochemical and molecular changes of the human pituitary adenomas. The article outlines individual tumor groups with general, specific and molecular findings. The discussion further extends to the unusual adenomas or carcinomas. The description in this article are pertinent not only for the practicing pathologists who are in the position of making proper diagnosis, but also for the pituitary research scientists who engage in solving basic problems in pituitary neoplasms by histochemistry and molecular biology.
\end{abstract}

Keywords Pituitary - Adenoma - Pathology ·

Histochemistry $\cdot$ Cell biology

\section{Introduction}

The pituitary adenomas are either clinically functioning adenomas or non-functioning adenomas. The former

R. Y. Osamura $(\bowtie) \cdot$ H. Kajiya $\cdot$ M. Takei $\cdot$ N. Egashira $\cdot$

M. Tobita $\cdot$ S. Takekoshi

Department of Pathology, Tokai University School of Medicine, 143 Shimokasuya, Boseidai Isehara, Kanagawa 259-1193, Japan e-mail: osamura@is.icc.u-tokai.ac.jp

M. Takei $\cdot$ A. Teramoto

Department of Neurosurgery, Nippon Medical School, 1-1-5 Sendagi, Bunkyo-ku, Tokyo 113-8603, Japan

M. Tobita

Division of Diabetes, Metabolism and Endocrinology, Jikei University School of Medicine, 3-25-8 Nishishinbashi, Minato-ku, Tokyo 105-8461, Japan includes GH secreting (cell) adenomas (abbreviated as GHomas), prolactin (PRL) secreting (cell) adenomas (PRLomas), TSH secreting (cell) adenomas (TSHomas), ACTH secreting (cell) adenomas (ACTHomas), and FSH secreting (cell) adenomas (FSHomas) (Fig. 1). LHomas are rather rare. Frequent adenomas among these are GHomas and PRLomas, the remaining tumors are rather rare. The rest of the adenomas are clinically "non-functioning". It should be particularly emphasized that majority of clinical nonfunctioning adenomas have been disclosed to be positive of gonadotropin subunits (SUs). The WHO Classification of the Endocrine Tumors follows this concept (Table 1). Except for ACTHomas, the pituitary adenomas are usually macroadenomas (Fig. 2). Sometimes, supra-sellar extension and downward sinus invasion are observed. Very occasionally, the pituitary adenomas can occur ectopically most frequently in the sphenoid sinuses. Pituitary carcinoma is very rare. Metastatic carcinoma to the pituitary is sometimes seen, its autopsy findings are not extremely rare and common primary sites include carcinoma of the lung. The pertinent diagnostic features and characteristics are described pointing out (1) general findings, (2) specific findings, (3) non-surgical therapy and therapy-related changes and (4) molecular findings.

Since Rosenfeld et al. (Nelson et al. 1988; Sornson et al. 1996) and Karin et al. (Bodner et al. 1988) reported the cloning of pituitary-specific transcription factor-1 (Pit-1), or POU1F1 or GHF-1, many transcription factors have been reported and it is generally known that the functional differentiation of the pituitary cells are dependent on the combination of transcription factors and co-factors (Fig. 3). It has been also known that the human pituitary cells show the colocalization of GH and $\alpha \mathrm{SU}$ in the normal condition and GHomas (Osamura 1988) (Table 2). 


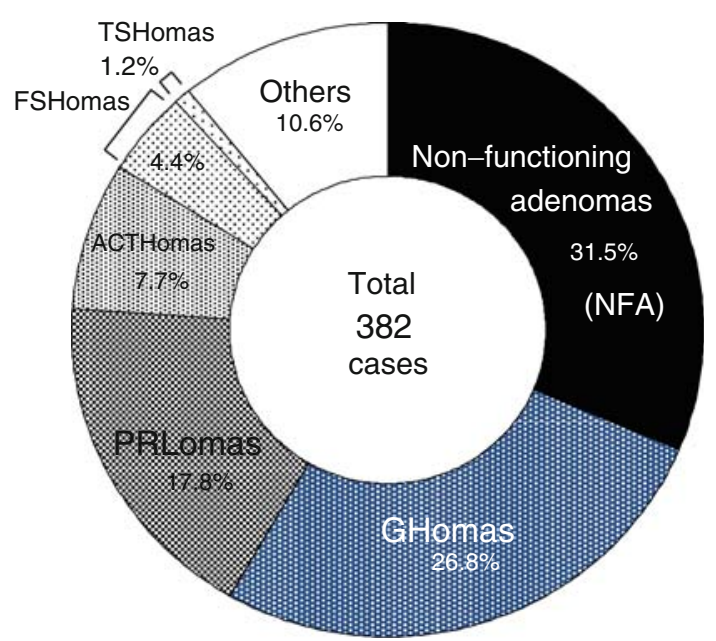

Fig. 1 Pathological diagnosis in pituitary adenomas. A total of 382 pituitary adenomas are classified with functional classifications using histology, IHC, ultrastructural features as well as biochemical, imaging and surgical findings in surgical resection at Nippon Medical School since 1977. The tumor cells in FNA are positive for gonadotropin $\mathrm{SU}$, and belonging to gonadotropin producing adenoma

Table 1 Classification of pituitary tumors, 2004 (WHO)

\begin{tabular}{|c|c|}
\hline GH producing adenoma & Gonadotropin producing adenoma \\
\hline Densely granulated adenoma & Unusual plurihormonal adenoma \\
\hline Sparsely granulated adenoma & Silent subtype 3 adenoma \\
\hline \multicolumn{2}{|l|}{ Mixed adenoma } \\
\hline Mammosomatotroph adenoma & Null cell adenoma \\
\hline Acidophilic stem cell adenoma & $\begin{array}{l}\text { Hormone immuno-negative } \\
\text { adenoma }\end{array}$ \\
\hline PRL producing adenoma & Oncocytoma \\
\hline \multicolumn{2}{|l|}{ Densely granulated adenoma } \\
\hline Sparsely granulated adenoma & Others \\
\hline Acidophilic stem cell adenoma & Carcinoma \\
\hline TSH producing adenoma & Atypical adenoma \\
\hline \multicolumn{2}{|l|}{ ACTH producing adenoma } \\
\hline \multicolumn{2}{|l|}{ Silent ACTH cell adenoma } \\
\hline \multicolumn{2}{|l|}{ Subtype 1} \\
\hline Subtype 2 & \\
\hline
\end{tabular}

\section{GH-producing (cell) adenoma (GHomas)}

General findings

It has been well documented that GHomas, which are secreting growth hormone in excess show two clinically related phenotypes, acromegaly and gigantism, depending on patient age at the onset of disease. In immunohistochemistry (IHC), it shows many GH positive tumor cells (Fig. 4b) and frequently, the tumor cells are also positive for PRL (Fig. 4c) and $\alpha$-glycoprotein subunit ( $\alpha \mathrm{SU}$ ) (Fig. 4d). The remaining hormones are also occasionally positive but ACTH is very rare. GHomas can classify, into five distinct adenomas (DeLellis et al. 2004; Vidal et al. 2004). The distinctions can affect the medical treatment in the event of surgeries (Bhayana et al. 2005; Ezzat et al. 1995), therefore accurate classification is very important. Of the five types, two are pure GH producing tumors, consisting of monomorphous GH cell are densely granulated, and sparsely granulated somatotroph adenomas. The others are plurihormonal tumors that include mammosomatotroph adenomas, mixed somatotroph-lactotroph adenomas, and acidophil stem cell adenomas (Vidal et al. 2004). By electron microscopy, many tumors are the type of "densely granulated cells" which contain many dense cored numerous secretory granules. Densely granulated adenomas (DGAs) are composed of large or medium size, round or polyhedral acidophilic cells with numerous secretory granules $(400-500 \mathrm{~nm})$ in the cytoplasm, and shows strong, uniform and diffuse cytoplasmic immunoreactivity for $\mathrm{GH}$ (Fig. 5a). DGA type, $<3 \%$ of nuclei are MIB-1 positive, and known to be slow growing and reactively non invasive (DeLellis et al. 2004; Hagiwara et al. 2003). Sparsely granulated adenomas (SGAs) composed of small round, partly irregular cell harboring a round nucleus with conspicuous nucleoli. They have relatively a fewer secretory granules $(100-250 \mathrm{~nm})$. The cells are chromophobic, and immunoreactivity for GH is weak (Fig. 5b). These types of adenomas are aggressive, and varying degrees of nuclear and cellular pleomorphism are seen (Horvath et al. 1997). Fibrous bodies are feature for this type of adenoma as mentioned below. Mammosomatotroph adenomas are morphologically close to densely granulated somatotroph adenoma and contain abundant and large secretory granules reaching up to $1,500 \mathrm{~nm}$. IHC shows single cell type reactive for both GH and PRL. Mixed somatotroph-lactotroph adenomas are most commonly consisting of densely granulated somatotropes and sparsely granulated lactotropes. Histologically, the adenomas consist of acidophilic cells interspersed with chromophobic. IHC elucidate that GH and PRL are immunostained in different cell populations.

Specific findings

\section{Fibrous (keratin) bodies}

In some GHomas, the tumor cells contain perinuclear globules of keratin by IHC. These globules have been called as fibrous bodies or recently keratin bodies. Fibrous bodies are strongly reactive for low molecular weight cytokeratins, particularly keratin 8 (DeLellis et al. 2004). Immunohistochemical staining confirms that the globules are composed of an admixture of intermediate filaments and smooth endoplasmic reticulum, are located in the Golgi region, and often indents the nucleus (Neumann et al. 1985; Vidal et al. 
Fig. 2 A pie chart of the ratio of nomas. Pituitary adenomas are ordinary macroadenomas except for ACTHomas pituitary macro and micro ade-
Fig. 3 Human pituitary cell linage. Pituitary-specific or related transcription factors involved in the development of pituitary gland. $\alpha \mathrm{SU}$ is expressed in some of the normal human GH-producing cells and some cases of $\mathrm{GH}$-producing adenomas as it occurs in mice
GHomas

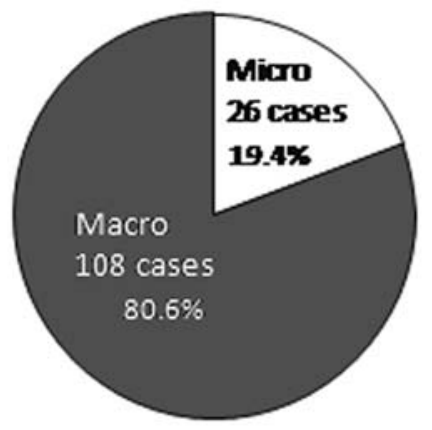

ACTHomas (Chshing's diseases)

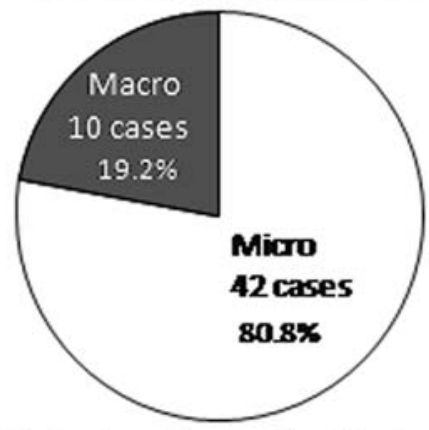

PRLomas
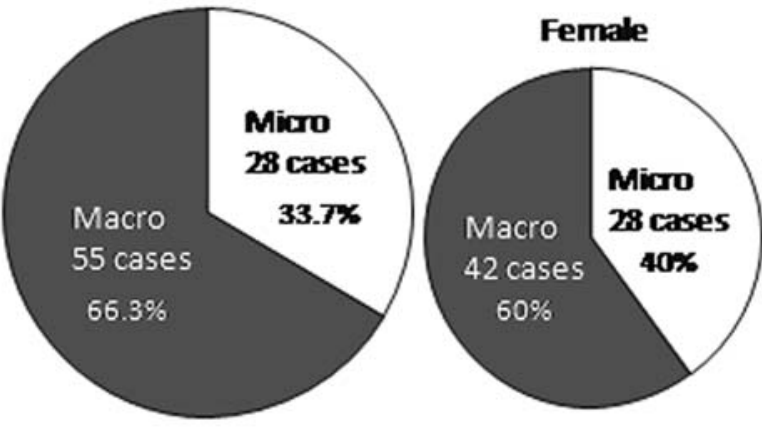

TSHomas

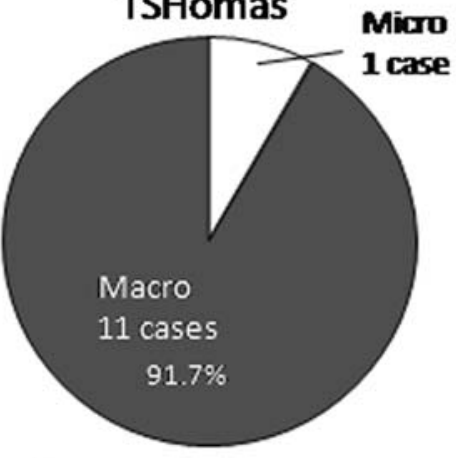

11 silent corticotroph cell adenomas:macroadenomas

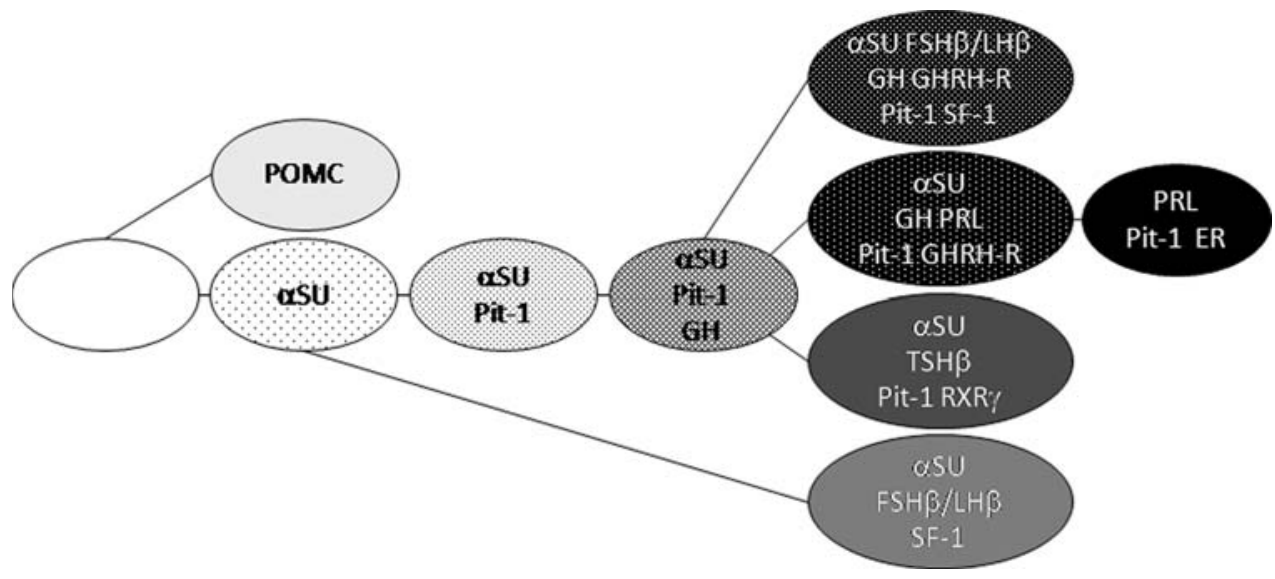

Table 2 Immunoprofile of hormones in pituitary adenomas (\%)

GH PRL ACTH FSH $\beta$ LH $\beta$ TSH $\beta \quad \alpha$ SU

\begin{tabular}{lccccccc}
\hline GHomas (69 cases) & 100 & 82.6 & 1.5 & 4.3 & 1.5 & 2.9 & 56.5 \\
TSHomas $(6$ cases) & 83.3 & 83.3 & 16.7 & 0 & 0 & 100 & 83.3 \\
FSHomas (11 cases) & 0 & 27.3 & 18.2 & 100 & 9.1 & 63.6 & 100 \\
PRLomas (27 cases) & 3.7 & 100 & 0 & 0 & 3.7 & 3.7 & 3.7 \\
ACTHomas $(15$ cases) & 6.7 & 13.3 & 100 & 0 & 6.7 & 0 & 33.3 \\
NFomas* $(197$ cases) & 4.6 & 10.2 & 5.1 & 42.6 & 19.8 & 2.0 & 43.1 \\
Total 325 cases & & & & & & &
\end{tabular}

* Non-functioning adenomas including $37.6 \%$ null cell adenomas

2004) (Fig. 6d). Fibrous bodies are the feature of sparsely granulated somatotroph adenoma type. The more granulated adenomas, including mammosomatotrophs and pluri- hormonal lesions, identifies some perinuclear keratin (Fig. 6c), but the sparsely granulated adenomas clearly decorates globules of keratin by immunostainig using CAM 5.2 keratin (CK8) (Fig. 6a-b).

\section{Stellate amyloid}

Very occasionally, GHomas show "stellate" amyloid among the tumor cells. The amyloid is positive for Congo red and is birefringent. By electron microscopy, the amyloid is composed of bundles of fine filaments, which appear to be typical for the amyloid of other origin and nature. Immunohistochemically, the tumor cells are strongly positive for GH and the amyloid is also weakly positive for $\mathrm{GH}$ (Osamura et al. 1982). 

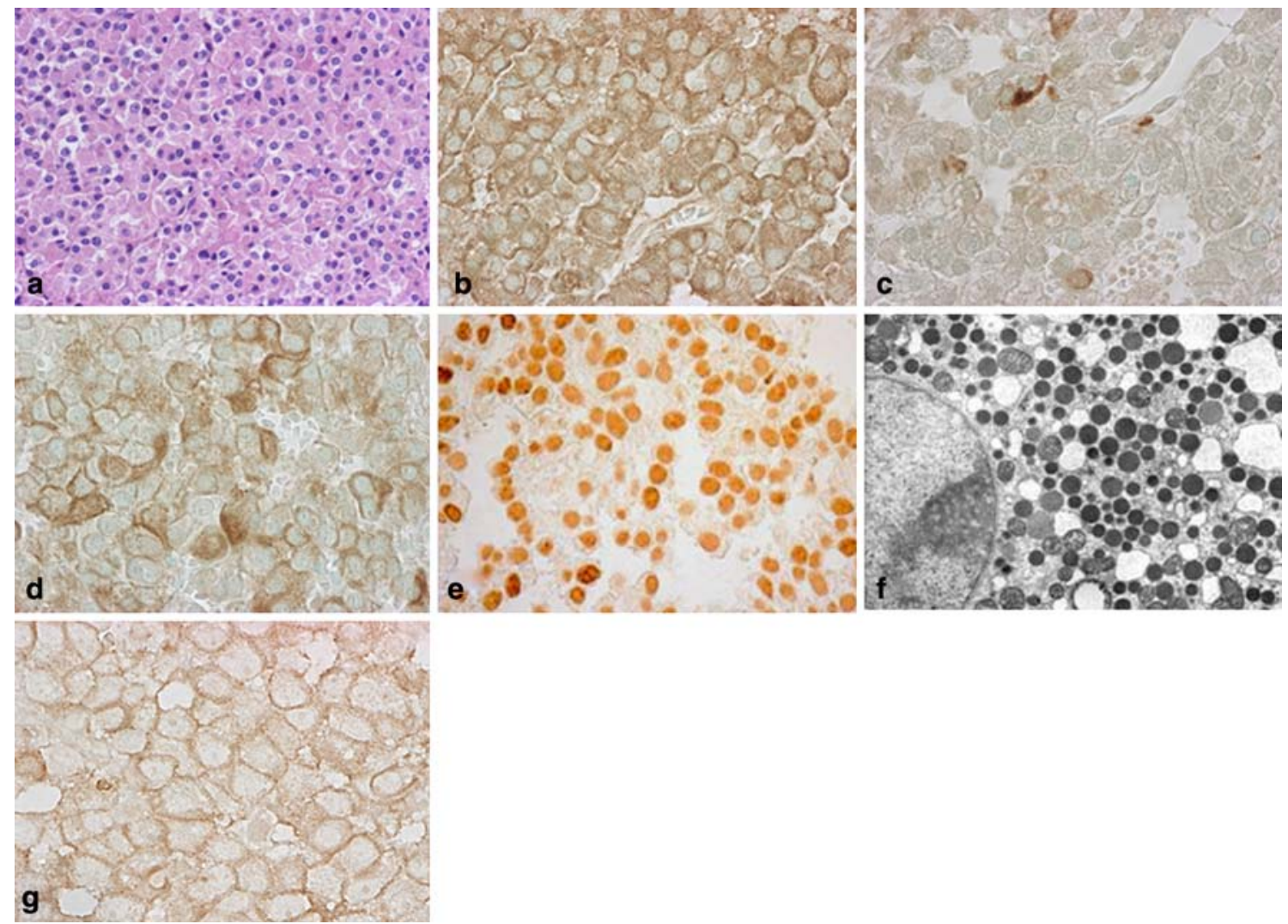

Fig. $4 \mathrm{GH}$ producing (cell) adenoma (GHoma). The tumor cells of hematoxylin eosin (H\&E) staining (a). In IHC, it shows many GH positive tumor cells (b), frequently cells are also positive for PRL (c) and $\alpha \mathrm{SU}$ (d). The IHC of pituitary-specific transcription factor 1 (Pit-1), which regulate the functional differentiation of GH-PRL-TSH cell

lineage (e). In electron microscopy, many GHoma are type of densely granulated cells, which contain many dense cored numerous secretory granules (f). SSTR2a is immunostained in cell membrane (g), which provides important information for SSAs therapy
Fig. 5 The IHC of GH of densely and sparsely granulated adenomas. Densely granulated adenoma shows strong and diffuse cytoplasmic immunoreactivity for GH (a). Sparsely granulated adenomas show weak GH immunostaining (b)
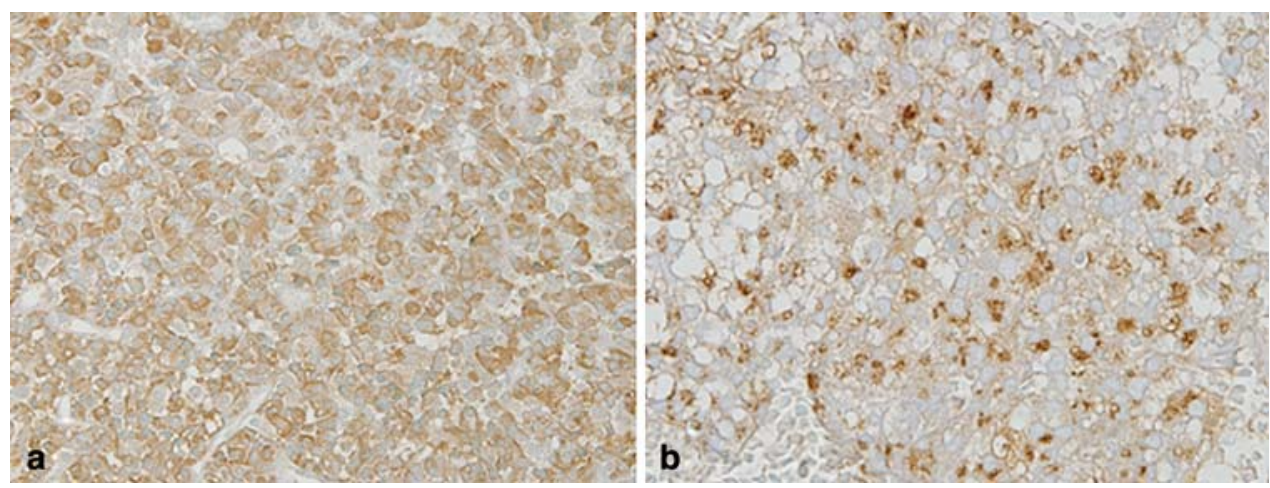

Changes induced by Octoreotide

In GHoma, treatment with long-acting somtostatin analogs (SSAs) called octreotide (SMS 201-995) results in reducing blood GH level, and tumor shrinkage in 40-50\% of patients, especially in those with receptor for somatostatin (Ezzat et al. 1992; Kovacs and Horvath 2005). Octreotide has high affinity for somatostatin receptor (SSTR) 2 and SSTR5. Takei et al. (2007) determined the expression of SSTR2 and
SSTR5 by IHC and compared this with the results of octreotide suppression testing before surgery to define whether IHC of SSTR could be associated with the preoperative response to octreotide. They concluded that the percentage of cell membrane immunopositive for SSTR2 is associated with the hormone inhibitory effect, so immunohistochemical analysis of SSTR in GHoma could provide important information for predicting the likelihood of successfully employing SSAs in adjuvant therapy (Fig. 4f). 
Fig. 6 The IHC of CAM 5.2 keratin (CK8). In some GHomas, the tumor cells shows globules of keratin, which are called as fibrous bodies, by IHC (a). b Shows magnified image of dot type fibrous bodies. In granulated adenomas, keratin is immunostained in cytoplasm (c). In electron microscopy, fibrous bodies shows smooth endoplasmic reticulum located in the Golgi region $(\mathbf{d})$

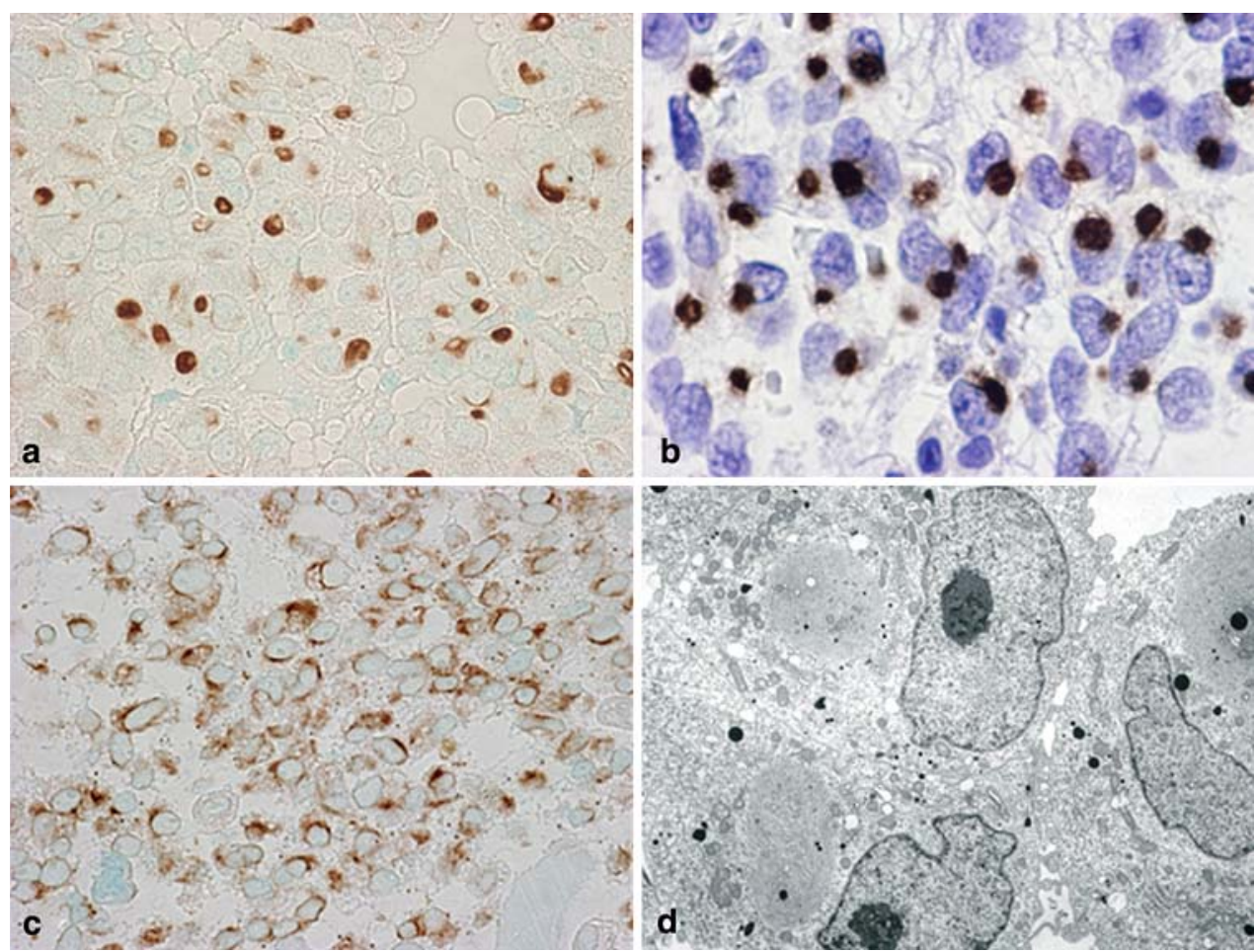

Silent somatotroph adenomas

These are the pituitary adenomas without clinical symptoms but show positive for specific hormones by IHC in the individual tumor cells. Silent somatotroph adenoma expresses $\mathrm{GH}$ and its mRNA without evidence of acromegaly (Naritaka et al. 1999).

Molecular findings

According to the previous studies on the functional development of the pituitary adenomas, it has been clarified that the functioning pituitary adenomas generally follows the combination of transcription factors and co-factors which have been known to function in the physiologic condition (Minematsu et al. 2005; Sanno et al. 2001). For example, GHomas are regulated by Pit-1 (Fig. 4e), which regulate the functional differentiation of GH-PRL-TSH cell lineage (Lee et al. 2005; Miyai et al. 2005) and positive in the nuclei of many tumor cells, and growth hormone-releasing hormone receptor (GHRH-R) (Matsuno et al. 1999; Sanno et al. 1997). Pituitary adenomas sometimes express more than one or two hormones. In our series, about $80 \%$ of GHomas are positive for PRL, and $56 \%$ of them are positive for $\alpha$ SU. Therefore, GHomas are plurihormonal tumors. Occasionally, GHomas also produce ACTH, which belongs to a different lineage, in the same tumor cells. For the molecular mechanism, aberrant combination of transcription factors has been proposed (Osamura et al. 2004). Some specific genes have been identified that predispose the hereditary pituitary adenomas. The multiple endocrine neoplasia (MEN1) gene, a tumor suppressor, is located on chromosome 11q13 frequently associated with GHoma and PRLoma (Chandrasekharappa et al. 1997). Somatic mutations in the $\alpha$-subunit of the Gs protein, which led to a constitutive activation of adenylyl cyclase, are reported in about $40 \%$ of $\mathrm{GH}$-producing pituitary adenomas (Landis et al. 1990).

\section{PRL producing (cell) adenomas (PRLomas)}

\section{General findings}

The tumor cells are classically chromophobic and immunohistochemically contain condensed PRL in the Golgi regions near the nuclei (Nebenkern; Golgi pattern) (Fig. 7a-b). PRLomas are usually mono-hormonal. No other hormones are detected by IHC. By electron microscope (EM), the tumor cells contain prominent Golgi saccules and a few small NSGs (Fig. 7c). Clinically, they are associated with manifestation due to the prominent increase in serum PRL levels (hyperprolactinemia) which are usually parallel to the tumor size. They can be electron microscopically classified into sparsely granulated and densely granulated type. The most frequent tumor type is sparsely granulated and they usually show high response to dopamine agonists (Al-Brahim and Asa 2006). Calcospherites or psammoma bodies are sometimes found (DeLellis et al. 2004). Densely granulated adenoma is rare, and is 
Fig. 7 PRL producing (cell) adenoma (PRLoma). The tumor cells of hematoxylin eosin (H\&E) staining (a) and IHC of PRL, which shows condense in the Golgi regions near the nuclei (b). In electron microscopy, prominent Golgi saccules and a few small NSGs are seen (c). d shows the extrusion of secretory granules, so called "misplaces exocytosis"
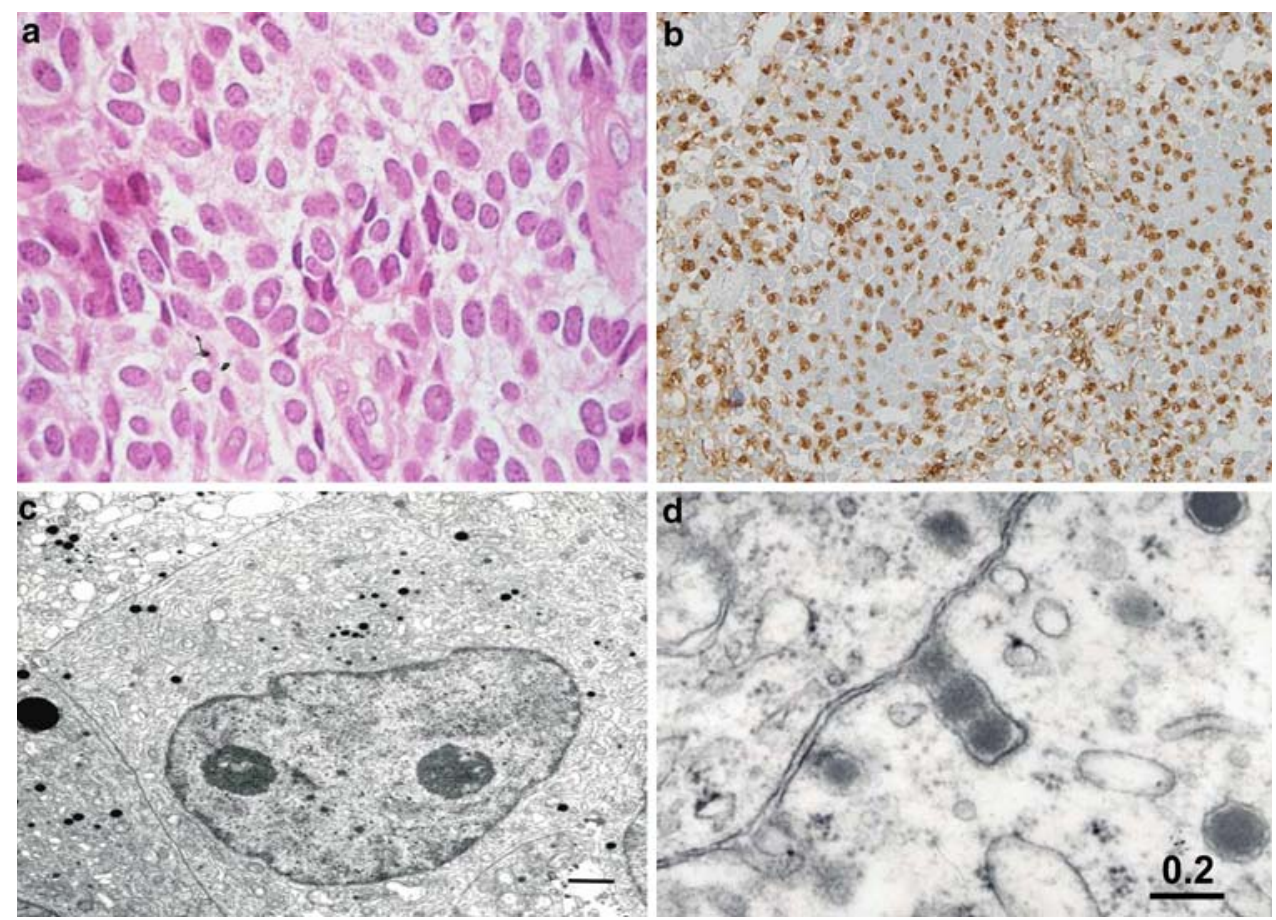

composed of acidophilic to chromophobic cells with abundant and diffuse cytoplasmic PRL granules. Clinically, GHPRL adenomas with the exception of acidophil stem cell adenomas are also characterized by hyper prolactinemia.

\section{Specific findings}

Immunohistochemical staining of the "Golgi pattern" is quite unique. Electron microscopically, the extrusion of secretary granules along the lateral cell surfaces into the extracellular space, so-called "misplaced exocytosis", has been regarded as a specific feature of the sparsely granulated PRLoma (DeLellis et al. 2004; Vidal et al. 2004) .

\section{Changes induced by Bromocriptine}

In the tumors from the patients with effective treatment by a dopamine agonist, Bromocriptine (BC), the tumor cells contain accumulated secretory granules. The induction of adenoma cells shrinkage and marked decrease in serum PRL level were observed in BC treatment (Kovacs and Horvath 2005). It has also been reported that BC induces exocytosis of the granules though there was a reduction in serum PRL revels (Mori et al. 2001).

\section{Molecular findings}

It has been reported that most PRLomas are immunohistochemcially positive for Pit-1 and estrogen receptor (ER). The binding sites for Pit-1 and ER are close enough to syn- ergize for the production of PRL. PRL cells are of extreme differentiation and most PRLomas are mono-hormonal. Recently, the pituitary tumor transforming gene (PTTG) has been suggested to be expressed in high levels in different pituitary tumor and to play a central role in pituitary tumorigenesis (Yu and Melmed 2004). The role of PTTG in prolactinomas is not clear but PTTG might involve lactotroph angiogenesis in pituitary adenomas in correlation with the increase in estrogen action (Cristina et al. 2007).

\section{ACTH producing (cell) adenomas (ACTHomas)}

General findings

ACTH producing adenomas with Cushing's disease represent $10-15 \%$ of pituitary tumors (Trouillas 2002). Most tumors are microadenomas with the cells which are basophilic and strongly PAS-positive (Saeger et al. 2007). The tumor consists of monomorphic round cells arranged diffusely with a sinusoidal pattern (Robert and Hardy 1986). Some tumors are chromophobic and weakly PASpositive. By IHC, these tumors are immunoreactive for $\mathrm{ACTH}, \beta$-LPH and/or $\beta$-endorphin. The intensity of hormone immunoreactivity varies: basophilic adenomas tend to be strongly positive. In the presence of active ACTH producing adenomas, the non neoplastic coritotropes often show characteristic alterations in Crooke's cells. These cells are larger than normal ACTH cells and exhibit an interacytoplasmic hyaline ring (Crooke 1935). 
Specific findings

\section{Silent ACTH producing adenoma}

ACTH producing adenomas without clinical and/or biological signs of hypercorticolism may be discovered by the pathologist, is named as silent ACTH producing adenoma (Horvath et al. 1980; Lloyd et al. 1997). Some of them secrete high molecular weight ACTH (Reincke et al. 1987). The silent densely granulated ACTH adenoma is designated as subtype 1 adenoma (Kovacs and Horvath 1986). The second inactive is the sparsely granulated adenoma and is called subtype 2 adenoma. They are large, frequently invasive into the cavernous sinus and sphenoid sinus.

\section{Crooke's cell adenoma}

Corticotroph adenomas generally do not undergo Crooke's hyaline change. Nonetheless, rare adenomas composed of Crooke's cells are described as the Crooke's cell adenoma (Franscella et al. 1991). In H\&E staining sections, the cells were characterized by densely eosinophilic and hyaline cytoplasm (Fig. 8a). The hyaline material was strongly cytokeratin immunoreactive (Fig. 8c). EM showed the accumulation of intermediate filaments was massive (Fig. 8d). Compared with typical corticotroph adenomas, Crooke's cell adenomas are clinically aggressive. It typically presents as an invasive macroadenoma. In recent study, invasiveness was found in $72 \%$ of this adenoma.
They have a higher rate of recurrence than other corticotroph adenomas (George et al. 2003).

\section{Molecular findings}

In ACTH producing adenoma, the transcription factor NeuroD1 (Oyama et al. 2001) and Tpit (Lamolet et al. 2001) are positive. The tumor cells produce prohormone, proopiomelanocortin (POMC), from which ACTH is derived after proper proteolytic digestion by prohormone convertase (PC1/3). When PC2 is present, $\alpha$-melanotroph stimulating hormone $(\alpha \mathrm{MSH})$ is positive in the adenoma cells.

\section{TSH producing (cell) adenomas (TSHomas)}

\section{General findings}

TSH producing adenomas are not frequent (BertholonGregoire et al. 1999). The patients with TSHomas are frequently hyperthyroid presenting Graves' disease. Sometimes, the patients show high serum GH level or PRL level. The tumor is usually macroadenoma as with extensive invasion. The tumors are composed of choromophobic cells and exhibit sinusoidal growth pattern (Fig. 9a). By IHC, the tumor cells are positive for $\mathrm{TSH} \beta$ and $\alpha \mathrm{SU}$. The tumors are also sometimes multihormonal with positive staining for GH and PRL (Sanno et al. 1994, 1995). Electron micrographs of the adenoma, show that the tumor cells were
Fig. 8 Crooke cell adenoma. The Crooke cell adenoma of hematoxylin eosin (H\&E) staining, which is characterized by densely eosinophilic and hyaline cytoplasm (a). The IHC of $\operatorname{ACTH}(\mathbf{b})$. c Shows the image of CAM 5.2 (keratin) immunostaining. Electron microscopy showed the accumulation of massive intermediate filaments (asterisk) (d)
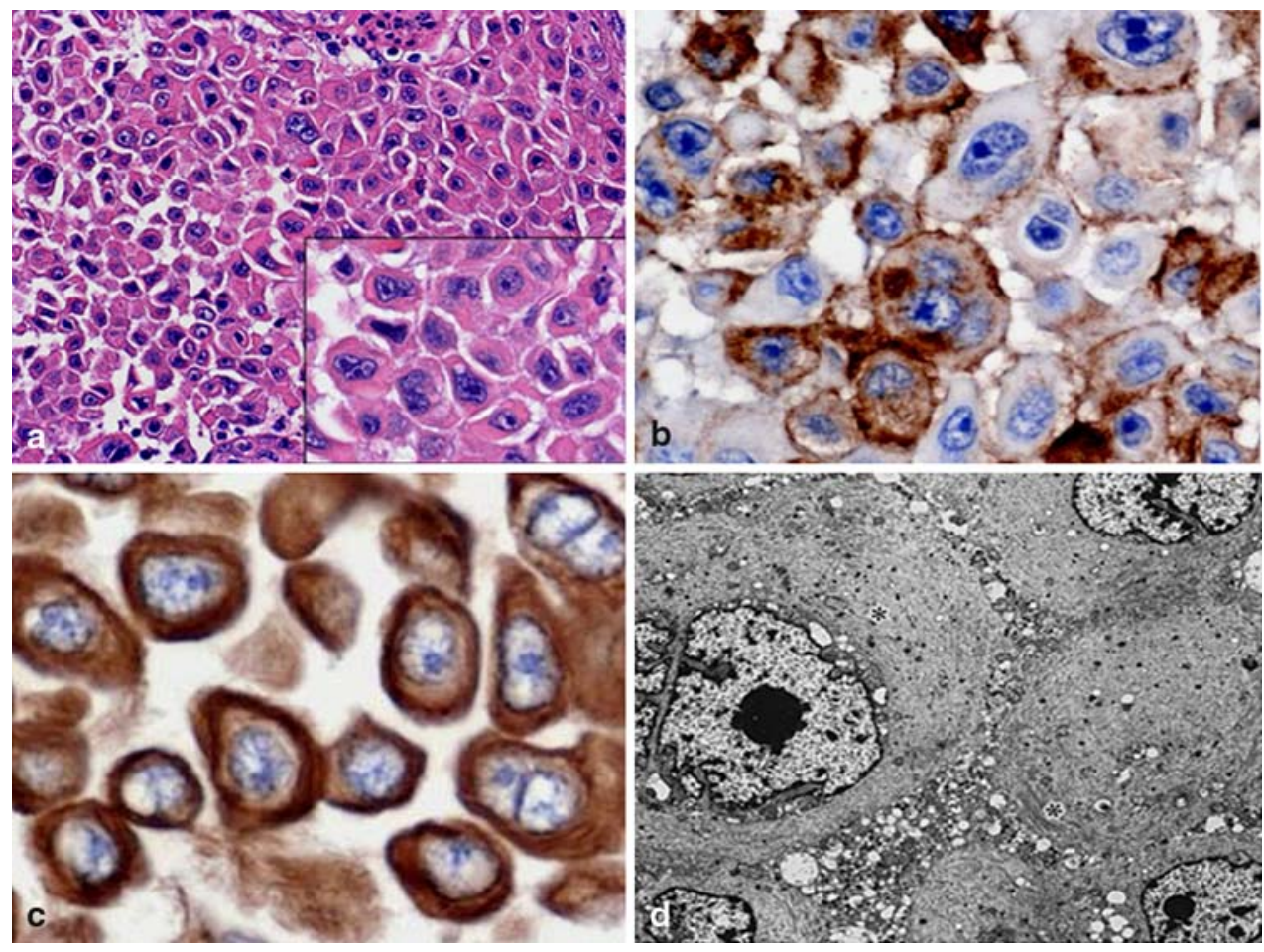
Fig. 9 TSH producing (cell) adenoma (TSHoma). The tumor cell of hematoxylin eosin (H\&E) staining (a). It is clearly showed by Heidenhain's azan stain, the stromal fibrosis in tumors (b)

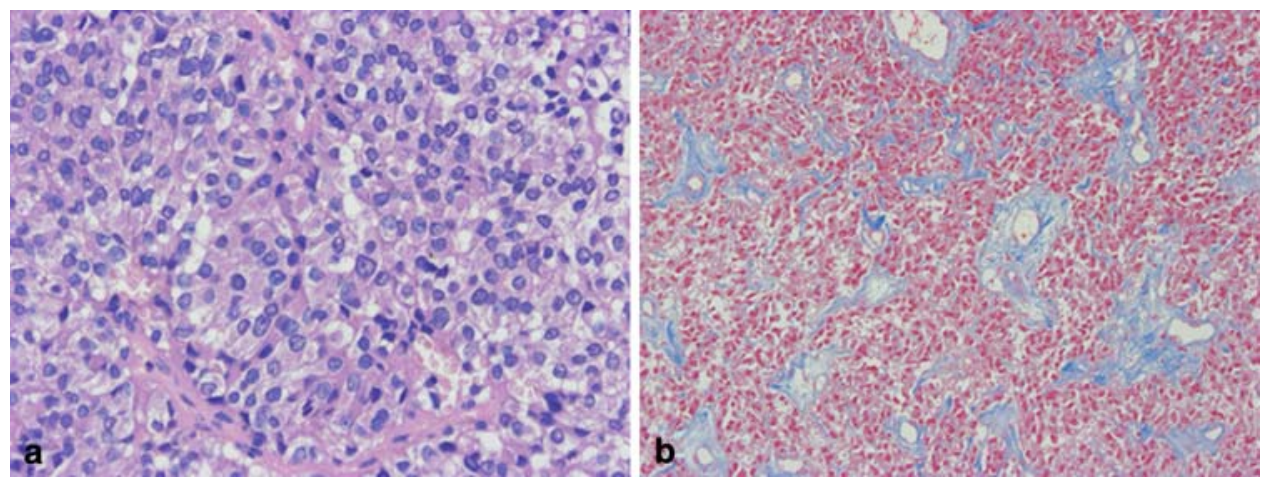

elongated and manifested with long cytoplasmic processes and round or ovoid nuclei with prominent nucleoli. There was a moderate development of rough endoplasmic reticulum and Golgi complexes. Small secretory granules measuring between 50 and $200 \mathrm{~nm}$ tend to accumulate along the cell membrane (Teramoto et al. 2004).

\section{Specific findings}

It has been pointed out by neurosurgeons that TSHomas are firm on their operation. By histology, the tumors frequently exhibit stromal fibrosis of various amounts among the tumor cells (Fig. 9b). Ocasional psammoma bodies are also observed.

\section{Molecular findings}

The tumors are multihormonal with the concomitant production of TSH, GH and PRL (Fig. 10a-c). As transcription factors, Pit-1 (Fig. 10d) and GATA-2 (Fig. 10e) have been synergistic for the production of TSH. Pit-1 also regulates GH and PRL.

\section{Gonadotropin producing adenomas}

FSH producing adenomas (FSHomas)

\section{General findings}

Light microscopically, this type of tumors shows frequent unique morphology by H\&E staining which is characterized by many chromophobic spindle cells arranged in "pseudorosette" patterns (Fig. 11c). Immunohistochemically, the tumor cells are frequently positive for FSH $\beta$ SU and $\alpha \mathrm{SU}$ (Fig. 11d-e). LH $\beta$ SU is seldom positive. By EM, the tumor cells show small secretory granules in the cytoplasm along with cell membrane.
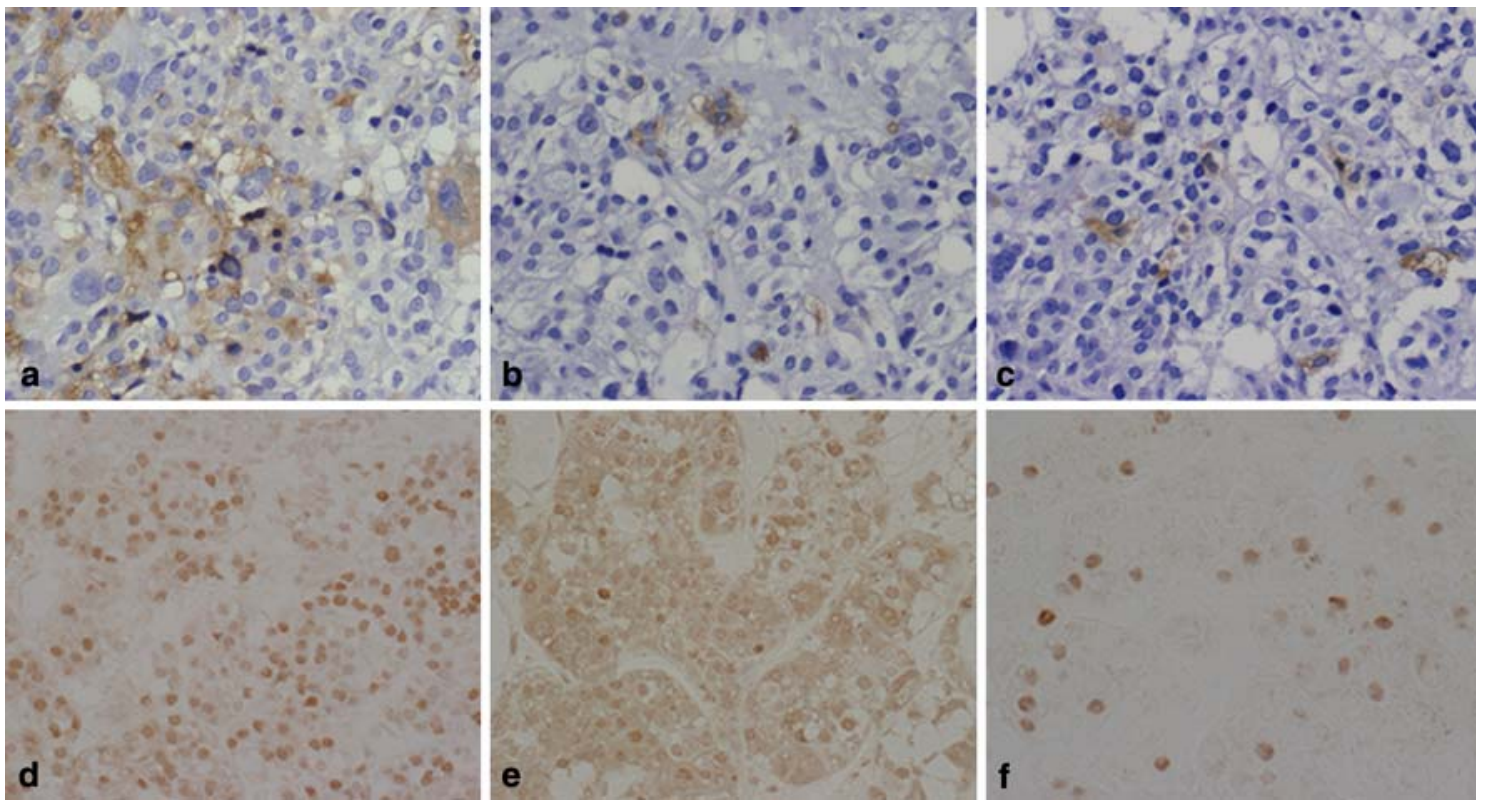

Fig. 10 IHC of TSH (TSHoma). It shows many TSH positive tumor cells (a), and multihormonal with the concominant production of PRL (b) and GH (c). For transcription factors, Pit-1 (d) and GATA-2 (e) are positive and sometimes ER (f) is positive 
Fig. 11 FSH producing (cell) adenoma (FSHoma). The tumor cells were organized into pseudorosette patterns (a). About $40 \%$ of FSHomas are immunopositive for $\alpha \mathrm{SU}$ (b), FSH $\beta$ SU (c) and SF-1 (d). In contrast, LH $\beta$ SU immunoreactivity is rare
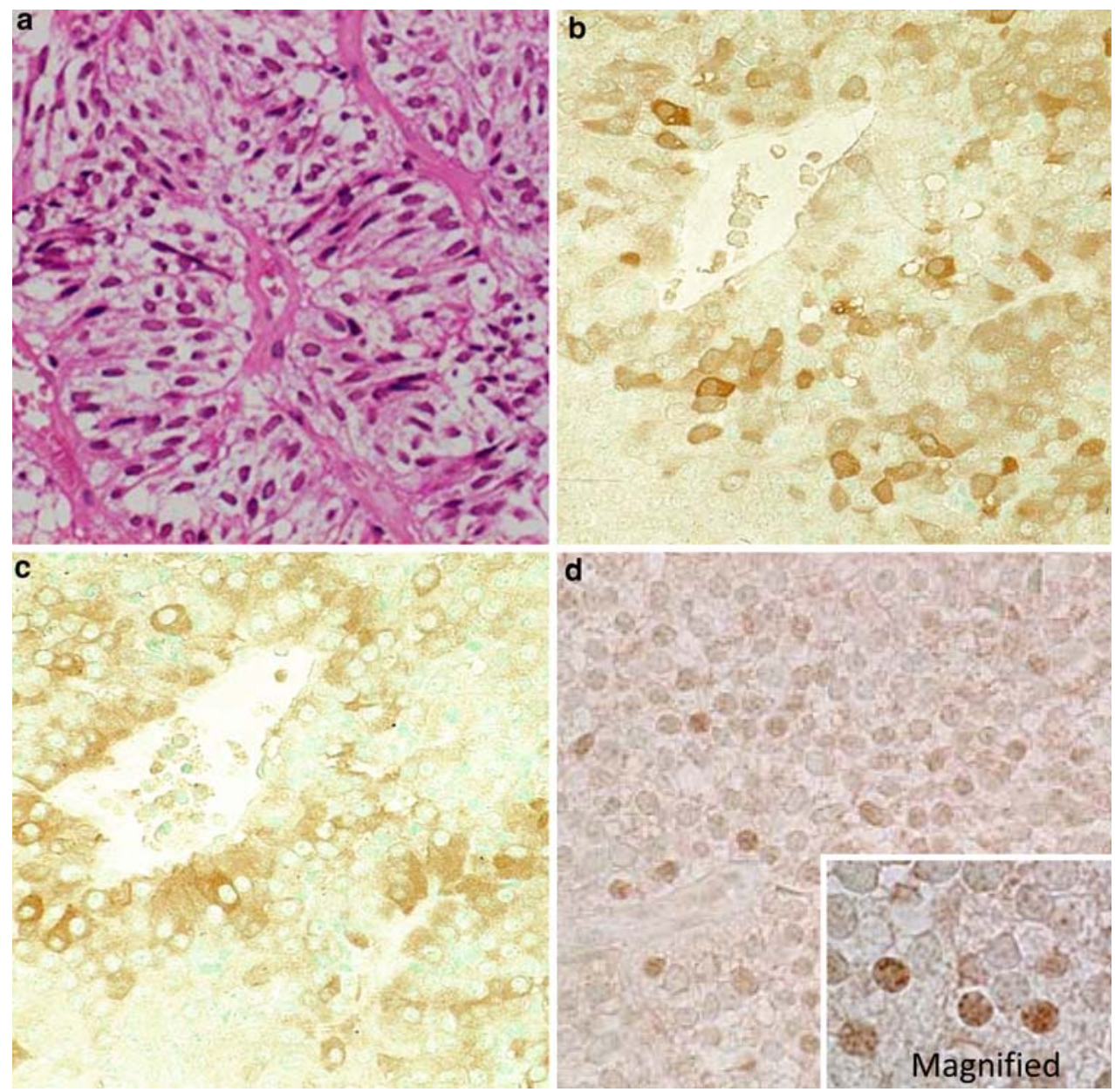

\section{Specific findings}

The above pseudorosette pattern is specific for this type of tumors. It is of particular interests that most FSHomas occur in male patients. Activin-signaling in male mouse gonadotropes may be different from the female-type gonadotropes. In male mouse pituitary cells, Smad stimulated expression of gonadotropins includes $\mathrm{LH} \beta$ and $\mathrm{FSH} \beta$ through the activin-signaling (Coss et al. 2005).

Gonadotropin subunits (SUs) producing adenomas (Gn-omas)

\section{General findings}

The nonfunctional pituitary adenomas have been shown to be derived from gonadotroph cells. And thus, almost all nonfunctional pituitary adenomas are termed Gn-omas. These tumors represent a half of all macroadenomas and present clinically in patients with visual field loss, headaches, hypogonadism, and hypopituitarism (Fig. 12a-b).
The tumors are mostly chromophobic and are composed of smaller pituitary cells.

\section{Specific findings}

Chromophobe cells without apparent pseudorosette patterns are specifically suggestive of Gn-omas. Focally, pseudorosette pattern is also observed. By IHC, about $40 \%$ of the tumors are positive for FSH $\beta$ SU and $\alpha \mathrm{SU}$. LH $\beta \mathrm{SU}$ is less frequent. It has been claimed that different tumor cells are positive for $\alpha \mathrm{SU}$ and $\beta \mathrm{SU}$ which account for the lack of specific function of FSH (Fig. 9c-d). Gn-omas with markedly increased mitochondria in the cytoplasm have been designated as oncocytomas.

\section{Molecular findings}

Most gonadotropinoma show FSH $\beta$ SU and $\alpha$ SU. Frequently, the tumors are also positive for TSH $\beta$ SU. The transcription factor steroidogenic factor-1 (SF-1) has been specific for gonadotropin production (Fig. 11f) (Asa et al. 1996). GATA-2 is an another transcription factor which synergizes with SF-1 to produce of TSH (Dasen et al. 1999). 

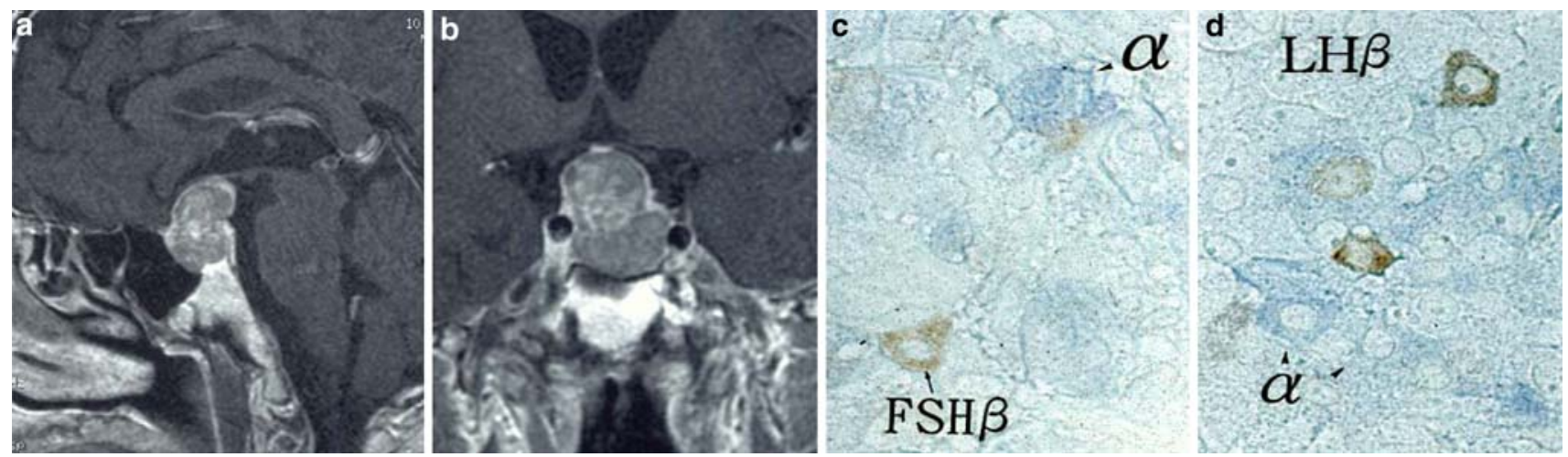

Fig. 12 Gonadotropin producing (cell) adenoma (Gn-oma). Mid-sagittal (a) and coronal (b) MRI image. The tumor cells present macroadenoma type and no evidence of bioactivities of hormone. $\alpha \mathrm{SU}(\mathbf{c}, \mathbf{d} ;$ blue $), \mathrm{FSH} \beta \mathrm{SU}(\mathbf{c} ;$ brown $)$ and LH $\beta \mathrm{SU}(\mathbf{d} ;$ brown $)$ are localized in different tumor cells

\section{Null cell adenomas}

General findings

When the tumor cells are immuno-negative for any pituitary hormones, the tumors have been designated as "null cell adenomas".

Specific findings

These types of adenomas includes chromophobic acidophilic or partly chromophobic, partly acidophilic with a diffuse pattern and elongated small cells forming psuedorosettes around the markedly dilated capillaries. Since some gonadotroph adenomas share the ultrastructural features of null cell adenomas, it is tempting to consider the latter as originating in a gonadotroph. The cells of null cell adenoma show a modest cytoplasm with poorly developed rough endoplasmic reticulum and Golgi apparatus, and rare round secretary granules, measuring up to $250 \mathrm{~nm}$ (Horvath and Kovacs 1984).

\section{Plurihormonal adenomas}

Silent subtype 3 adenoma

Silent subtype 3 adenomas are rare pituitary tumors that have immunoreactivities for more than one pituitary hormone. They are classified as unusual pulrihormonal adenomas in the World Health Organization (WHO) Classification of Endocrine Tumors (DeLellis et al. 2004). Silent subtype 3 adenomas are described by Horvath et al. (1980) for the first time from the ultrastructural characteristics.

Although they have much variation in terms of histology and IHC, the ultrastructures have been characteristic and diagnostic.

\section{Clinical features}

At the time of diagnosis, these tumors are usually macroadenomas. They are usually associated with hyperprolactinemia and often clinically mistaken for prolactinomas and treated especially in women. They sometimes display aggressive behavior with suprasellar or parasellar extension and also have a high recurrence rate. Complete surgical removal is sometimes difficult and the radiotherapy is done in postoperative management (Horvath et al. 1988).

Pathology

The adenoma cells are middle-sized or large, and polar. The euchromatic nuclei contain large prominent nucleolus and often a few fragments of nuclear inclusions (Spheridia) whose function is unknown. Nuclear spheria are not specific for subtype 3 adenoma, but abundant spheria are characteristic of the tumors (Horvath et al. 1988). The ample cytoplasm contains extensively distributed rough-surfaced endoplasmic reticulum, randomly distributed smooth-surfaced endoplasmic reticulum and large tortuous Golgi complex. The secretory granules of about $100-200 \mathrm{~nm}$ are numerous and tend to accumulate heavily in cell processes, which is a typical feature of glycoprotein hormone cell differentiation (Horvath et al. 2005). Immunohistochemically, the tumor cells are immunoreactive for mainly GH, PRL and TSH. However, they also have other varied combination of hormones and their cytogenesis remains unresolved.

\section{Pituitary adenomas with "translineage" differentiation}

Very occasionally, some human pituitary tumors demonstrate their functional differentiation toward the production of hormones belonging to different cell lineages, i.e., 
ACTHomas with GH production, GHomas with ACTH production, FSHomas with ACTH production and so on.

We have studied the cases of ACTHomas with GH production and GHomsa with ACTH production. These cases demonstrate both NeuroD1 and Pit-1 transcription factors in the tumor cells could induce "translineage" differentiation. We have postulated that "aberrant" expressions of transcription factors could be the cause of this abnormal differentiation in the tumors (Tahara et al. 2002).

\section{Pituitary adenomas with only early differentiation}

Some ACTHomas have been shown to be positive for $\mathrm{ACTH}$ and also positive for $\alpha \mathrm{SU}$ in the tumor cells. Five of 89 cases of ACTHomas showed this aberrant expression. In human pituitaries, it has been suggested that ACTH appears as a first hormone proceeding to $\alpha \mathrm{SU}$ (Osamura, personal observation by IHC). In human, two distinct differentiation pathways exist: (1) ACTH lineage and (2) gonado-GHPRL-TSH lineage.

These tumors only exhibiting ACTH and $\alpha \mathrm{SU}$ are of particular interests in considering their histogenesis. These tumors are considered to be derived from the primitive pituitary ACTH committed progenitor cells with aberrant expression of $\alpha \mathrm{SU}$. Detailed mechanisms remained to be further investigated (Suzuki et al. 2008).

\section{Special types of pituitary adenomas and carcinomas}

Even though the incidence is very rare, we see some cases of the very unique and special cases of the pituitary tumors. For this situation, IHC and molecular analysis are expected to play key roles in establishing diagnosis.

Fig. 13 H\&E staining of the tumor cells (a). Neuroendocrine marker SNAP25 (b) and pituitary hormone $\mathrm{FSH} \beta$ (c) and ACTH (d) are detected. e Electron microscopy shows dense cored secretory granules
Ectopic pituitary adenomas

It has been well documented that the pituitary adenomas can occur outside of sella turcica, most frequently in the sphenoid sinuses. The differential diagnoses contain olfactory neuroblastoma (esthesioneuroblastomas), rhabdomyosaromas and germinomas. The establishment of the proper diagnosis relies on immunohistochemical findings including neuroendocrine markers such as chromogranin A, synaptophysin and SNAP25 as well as some pituitary hormones. Especially, the detection of the pituitary hormones is diagnostic for this lesion (Fig. 13).

Invasive pituitary adenomas

Some intra-sellar pituitary adenomas can grow downward and invade the sphenoid sinuses. Various types of adenomas can present this growth pattern. A case of acute meningitis induced by invasive pituitary PRLomas has been reported as an autopsy case with a very short clinical history (Onoda et al. 1992).

\section{Pituitary carcinomas}

A few cases of pituitary carcinomas have been reported in the literature. Frequently, the pituitary carcinomas demonstrate liver metastasis. The tumor cells are more atypical than usual adenomas and show high MIB-1 proliferative indices. The tumors are frequently functioning, such as PRL producing or ACTH producing.

\section{Gangliocytoma}

This is a very rare tumor, which has been reported as a source for GHRH which stimulates hyperplastic GH cells (Kurosaki et al. 2002) (Fig. 14).
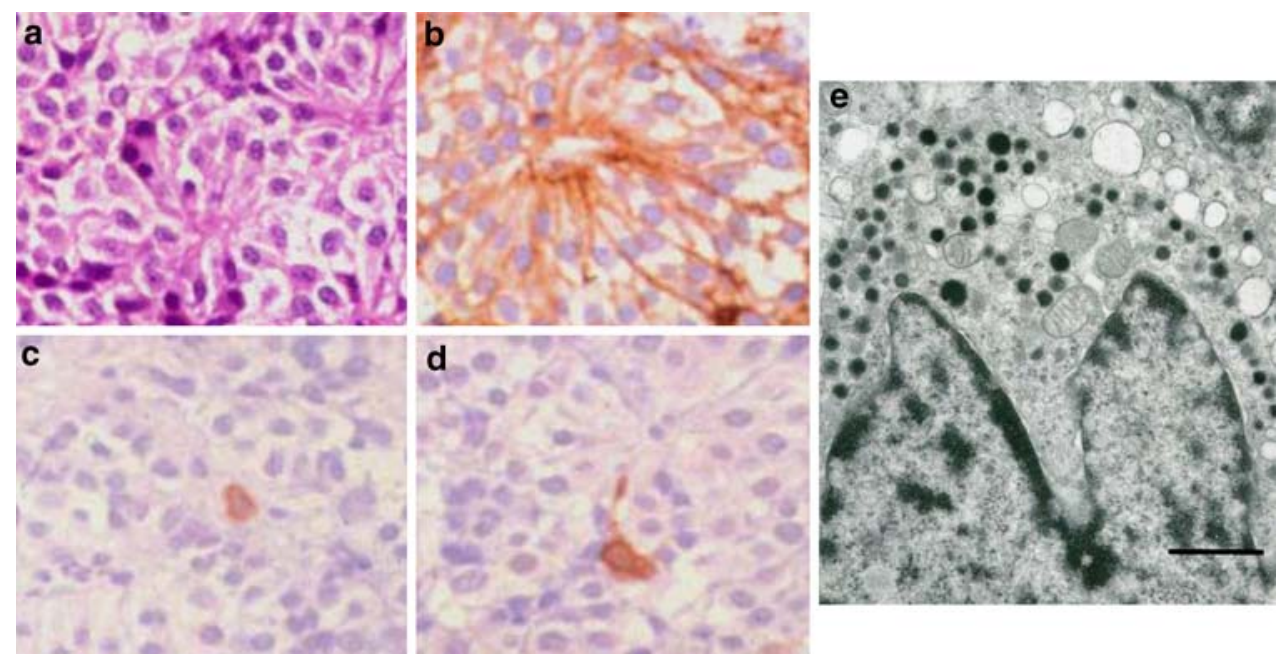
Fig. $14 H \& E$ staining of the tumor cells (a). IHC of GH (b) and GHRH (c). It is suggested that GHRH stimulates the hyperplastic GH cells
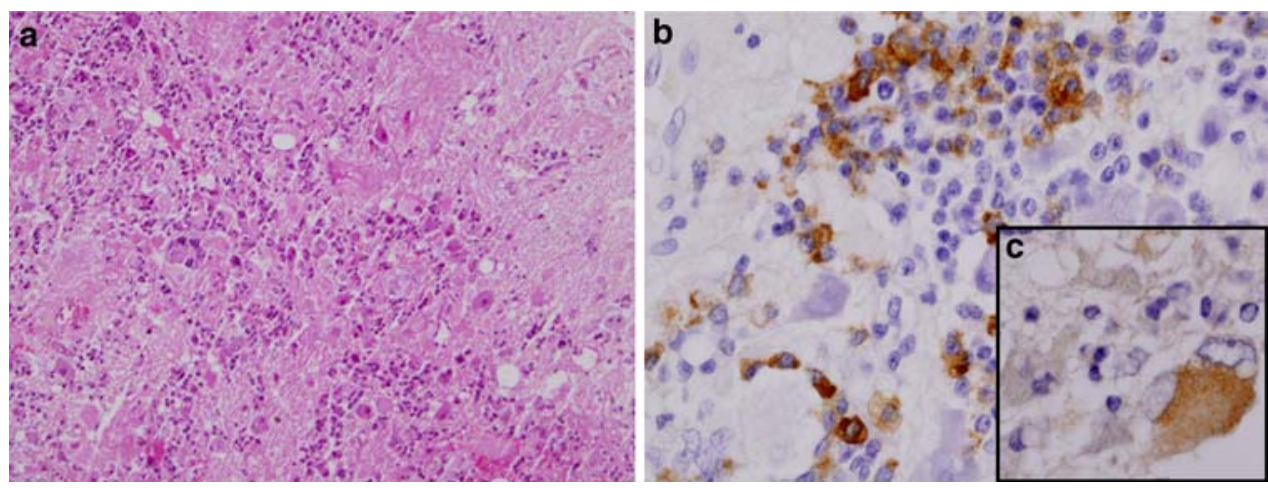

\section{Metastatic carcinomas}

The metastatic carcinomas in the pituitary region retain the morphologic features of the primary tumors or those of other metastatic sites. Primary lung cancer, especially the small cell carcinoma, has been experienced as a primary source of the metastatic carcinomas to the pituitary.

\section{PRLomas with Germinomas}

It is very rare occasion to see germinoma as an intra-sellar tumor. Morphologically, the tumor cells demonstrate typical features similar to testicular seminomas or ovarian dysgerminomas. A reported case of germinoma showed admixed foci of PRLomas (Sugiyama et al. 1999). The morphogenesis of this "mixed" tumor remains to be further investigated.

\section{References}

Al-Brahim NY, Asa SL (2006) My approach to pathology of the pituitary gland. J Clin Pathol 59:1245-1253

Asa SL, Bamberger AM, Cao B, Wong M, Parker KL, Ezzat S (1996) The transcription activator steroidogenic factor- 1 is preferentially expressed in the human pituitary gonadotroph. J Clin Endocrinol Metab 81:2165-2170

Bertholon-Gregoire M, Trouillas J, Guigard MP, Loras B, Tourniaire J (1999) Mono- and plurihormonal thyrotropic pituitary adenomas: pathological, hormonal and clinical studies in 12 patients. Eur $\mathbf{J}$ Endocrinol 140:519-527

Bhayana S, Booth GL, Asa SL, Kovacs K, Ezzat S (2005) The implication of somatotroph adenoma phenotype to somatostatin analog responsiveness in acromegaly. J Clin Endocrinol Metab 90:6290-6295

Bodner M, Castrillo JL, Theill LE, Deerinck T, Ellisman M, Karin M (1988) The pituitary-specific transcription factor GHF-1 is a homeobox-containing protein. Cell 55:505-518

Chandrasekharappa SC, Guru SC, Manickam P, Olufemi SE, Collins FS, Emmert-Buck MR, Debelenko LV, Zhuang Z, Lubensky IA, Liotta LA, Crabtree JS, Wang Y, Roe BA, Weisemann J, Boguski MS, Agarwal SK, Kester MB, Kim YS, Heppner C, Dong Q, Spiegel AM, Burns AL, Marx SJ (1997) Positional cloning of the gene for multiple endocrine neoplasia-type 1. Science 276:404-407

Coss D, Thackray VG, Deng CX, Mellon PL (2005) Activin regulates luteinizing hormone beta-subunit gene expression through Smadbinding and homeobox elements. Mol Endocrinol 19:2610-2623
Cristina C, Diaz Torga GS, Goya RG, Kakar SS, Perez-Millan MI, Passos VQ, Giannella-Neto D, Bronstein MD, Becu-Villalobos D (2007) PTTG expression in different experimental and human prolactinomas in relation to dopaminergic control of lactotropes. Mol Cancer 6:4

Crooke AC (1935) A change in the basophil cells of the pituitary gland common to conditions which exhibit the syndrome attributed to basophil adenoma. J Pathol Bacteriol 41:339-349

Dasen JS, O'Connell SM, Flynn SE, Treier M, Gleiberman AS, Szeto DP, Hooshmand F, Aggarwal AK, Rosenfeld MG (1999) Reciprocal interactions of Pit1 and GATA2 mediate signaling gradient-induced determination of pituitary cell types. Cell 97:587-598

DeLellis RA, Lloyd RV, Heitz PU, Eng C (2004) Pathology and genetics of tumors of endocrine organs, World Health Organization Classification of Tumors. IARC Press, Lyon, pp 9-45

Ezzat S, Snyder PJ, Young WF, Boyajy LD, Newman C, Klibanski A, Molitch ME, Boyd AE, Sheeler L, Cook DM et al (1992) Octreotide treatment of acromegaly. A randomized, multicenter study. Ann Intern Med 117:711-718

Ezzat S, Kontogeorgos G, Redelmeier DA, Horvath E, Harris AG, Kovacs K (1995) In vivo responsiveness of morphological variants of growth hormone-producing pituitary adenomas to octreotide. Eur J Endocrinol 133:686-690

Franscella S, Favrod-Coune CA, Pizzolato G (1991) Pituitary corticotroph adenoma with Crooke's hyalinization. Endocr Pathol 2:111-116

George DH, Scheithauer BW, Kovacs K, Horvath E, Young WF Jr, Lloyd RV, Meyer FB (2003) Crooke's cell adenoma of the pituitary: an aggressive variant of corticotroph adenoma. Am J Surg Pathol 27:1330-1336

Hagiwara A, Inoue Y, Wakasa K, Haba T, Tashiro T, Miyamoto T (2003) Comparison of growth hormone-producing and nongrowth hormone-producing pituitary adenomas: imaging characteristics and pathologic correlation. Radiology 228:533-538

Horvath E, Kovacs K (1984) Gonadotroph adenomas of the human pituitary: sex-related fine-structural dichotomy. A histologic, immunocytochemical, and electron-microscopic study of 30 tumors. Am J Pathol 117:429-440

Horvath E, Kovacs K, Killinger DW, Smyth HS, Platts ME, Singer W (1980) Silent corticotropic adenomas of the human pituitary gland: a histologic, immunocytologic, and ultrastructural study. Am J Pathol 98:617-638

Horvath E, Kovacs K, Smyth HS, Killinger DW, Scheithauer BW, Randall R, Laws ER Jr, Singer W (1988) A novel type of pituitary adenoma: morphological features and clinical correlations. J Clin Endocrinol Metab 66:1111-1118

Horvath E, Sheithauer BW, Kovacs K, Lloyd RV (1997) Pituitary adenomas. Oxford University Press, New York

Horvath E, Kovacs K, Smyth HS, Cusimano M, Singer W (2005) Silent adenoma subtype 3 of the pituitary-immunohistochemical 
and ultrastructural classification: a review of 29 cases. Ultrastruct Pathol 29:511-524

Kovacs K, Horvath E (1986) Pathology of growth hormone-producing tumors of the human pituitary. Semin Diagn Pathol 3:18-33

Kovacs K, Horvath E (2005) Effects of medical therapy on pituitary tumors. Ultrastruct Pathol 29:163-167

Kurosaki M, Saeger W, Ludecke DK (2002) Intrasellar gangliocytomas associated with acromegaly. Brain Tumor Pathol 19:63-67

Lamolet B, Pulichino AM, Lamonerie T, Gauthier Y, Brue T, Enjalbert A, Drouin J (2001) A pituitary cell-restricted T box factor, Tpit, activates POMC transcription in cooperation with Pitx homeoproteins. Cell 104:849-859

Landis CA, Harsh G, Lyons J, Davis RL, McCormick F, Bourne HR (1990) Clinical characteristics of acromegalic patients whose pituitary tumors contain mutant Gs protein. J Clin Endocrinol Metab 71:1416-1420

Lee EJ, Russell T, Hurley L, Jameson JL (2005) Pituitary transcription factor-1 induces transient differentiation of adult hepatic stem cells into prolactin-producing cells in vivo. Mol Endocrinol 19:964-971

Lloyd RV, Jin L, Qian X, Kulig E (1997) Aberrant p27kip1 expression in endocrine and other tumors. Am J Pathol 150:401-407

Matsuno A, Katakami H, Sanno N, Ogino Y, Osamura RY, Matsukura S, Shimizu N, Nagashima T (1999) Pituitary somatotroph adenoma producing growth hormone $(\mathrm{GH})$-releasing hormone $(\mathrm{GH}-$ $\mathrm{RH}$ ) with an elevated plasma GHRH concentration: a model case for autocrine and paracrine regulation of GH secretion by GHRH. J Clin Endocrinol Metab 84:3241-3247

Minematsu T, Miyai S, Kajiya H, Suzuki M, Sanno N, Takekoshi S, Teramoto A, Osamura RY (2005) Recent progress in studies of pituitary tumor pathogenesis. Endocrine 28:37-41

Miyai S, Yoshimura S, Iwasaki Y, Takekoshi S, Lloyd RV, Osamura RY (2005) Induction of GH, PRL, and TSH beta mRNA by transfection of Pit-1 in a human pituitary adenoma-derived cell line. Cell Tissue Res 322:269-277

Mori H, Saitoh Y, Maeda T, Okada Y, Hirano H, Tsuji M (2001) Increased exocytosis of secretory granules in contrast to reduced serum hormone levels in pituitary adenomas of humans and rats treated with dopamine agonist. Med Electron Microsc 34:123-133

Naritaka H, Kameya T, Sato Y, Furuhata S, Otani M, Kawase T (1999) Morphological characterization and subtyping of silent somatotroph adenomas. Pituitary 1:233-241

Nelson C, Albert VR, Elsholtz HP, Lu LI, Rosenfeld MG (1988) Activation of cell-specific expression of rat growth hormone and prolactin genes by a common transcription factor. Science 239:14001405

Neumann PE, Goldman JE, Horoupian DS, Hess MA (1985) Fibrous bodies in growth hormone-secreting adenomas contain cytokeratin filaments. Arch Pathol Lab Med 109:505-508

Onoda N, Kamezu Y, Takagi S, Shinohara Y, Osamura RY (1992) An autopsy case of invasive pituitary adenoma (prolactinoma) with rapid fatal clinical course due to streptococcal meningitis. Acta Pathol Jpn 42:832-836

Osamura RY (1988) Immunoelectron microscopic studies of GH and alpha subunit in GH secreting pituitary adenomas. Pathol Res Pract 183:569-571

Osamura RY, Watanabe K, Komatsu N, Ohya M, Kageyama N (1982) Amorphous and stellate amyloid in functioning human pituitary adenomas: histochemical, immunohistochemical and electron microscopic studies. Acta Pathol Jpn 32:605-611

Osamura RY, Egashira N, Miyai S, Yamazaki M, Takekoshi S, Sanno N, Teramoto A (2004) Molecular pathology of the pituitary. Development and functional differentiation of pituitary adenomas. Front Horm Res 32:20-33
Oyama K, Sanno N, Teramoto A, Osamura RY (2001) Expression of neuro D1 in human normal pituitaries and pituitary adenomas. Mod Pathol 14:892-899

Reincke M, Allolio B, Saeger W, Kaulen D, Winkelmann W (1987) A pituitary adenoma secreting high molecular weight adrenocorticotropin without evidence of Cushing's disease. J Clin Endocrinol Metab 65:1296-1300

Robert F, Hardy J (1986) Human corticotroph cell adenomas. Semin Diagn Pathol 3:34-41

Saeger W, Ludecke DK, Buchfelder M, Fahlbusch R, Quabbe HJ, Petersenn S (2007) Pathohistological classification of pituitary tumors: 10 years of experience with the German Pituitary Tumor Registry. Eur J Endocrinol 156:203-216

Sanno N, Teramoto A, Matsuno A, Inada K, Itoh J, Osamura RY (1994) Clinical and immunohistochemical studies on TSH-secreting pituitary adenoma: its multihormonality and expression of Pit-1. Mod Pathol 7:893-899

Sanno N, Teramoto A, Matsuno A, Takekoshi S, Osamura RY (1995) GH and PRL gene expression by nonradioisotopic in situ hybridization in TSH-secreting pituitary adenomas. J Clin Endocrinol Metab 80:2518-2522

Sanno N, Teramoto A, Osamura RY, Genka S, Katakami H, Jin L, Lloyd RV, Kovacs K (1997) A growth hormone-releasing hormone-producing pancreatic islet cell tumor metastasized to the pituitary is associated with pituitary somatotroph hyperplasia and acromegaly. J Clin Endocrinol Metab 82:2731-2737

Sanno N, Tahara S, Kurotani R, Matsuno A, Teramoto A, Osamura RY (2001) Cytochemical and molecular biological aspects of the pituitary and pituitary adenomas-cell differentiation and transcription factors. Prog Histochem Cytochem 36:263-299

Sornson MW, Wu W, Dasen JS, Flynn SE, Norman DJ, O'Connell SM, Gukovsky I, Carriere C, Ryan AK, Miller AP, Zuo L, Gleiberman AS, Andersen B, Beamer WG, Rosenfeld MG (1996) Pituitary lineage determination by the Prophet of Pit-1 homeodomain factor defective in Ames dwarfism. Nature 384:327-333

Sugiyama M, Takumi I, Node Y, Sanno N, Teramoto A, Osamura RY (1999) Neurohypophyseal germinoma with prolactinoma. Case illustration. J Neurosurg 90:170

Suzuki M, Egashira N, Kajiya H, Minematsu T, Takekoshi S, Tahara S, Sanno N, Teramoto A, Osamura RY (2008) ACTH and alphasubunit are co-expressed in rare human pituitary corticotroph cell adenomas proposed to originate from ACTH-committed early pituitary progenitor cells. Endocr Pathol 19:17-26

Tahara S, Kurotani R, Ishii Y, Sanno N, Teramoto A, Osamura RY (2002) A case of Cushing's disease caused by pituitary adenoma producing adrenocorticotropic hormone and growth hormone concomitantly: aberrant expression of transcription factors NeuroD1 and Pit-1 as a proposed mechanism. Mod Pathol 15:11021105

Takei M, Suzuki M, Kajiya H, Ishii Y, Tahara S, Miyakoshi T, Egashira N, Takekoshi S, Sanno N, Teramoto A, Osamura RY (2007) Immunohistochemical detection of somatostatin receptor (SSTR) subtypes $2 \mathrm{~A}$ and 5 in pituitary adenoma from acromegalic patients: good correlation with preoperative response to octreotide. Endocr Pathol 18:208-216

Teramoto A, Sanno N, Tahara S, Osamura YR (2004) Pathological study of thyrotropin-secreting pituitary adenoma: plurihormonality and medical treatment. Acta Neuropathol 108:147-153

Trouillas J (2002) Pathology and pathogenesis of pituitary corticotroph adenoma. Neurochirurgie 48:149-162

Vidal S, Horvath E, Kovacs K, Scheithauer BW (2004) Tumors of the Adenohypophysis. Humana Press, Totowa

Yu R, Melmed S (2004) Pituitary tumor transforming gene: an update. Front Horm Res 32:175-185 